Research Article

Journal of Extension Education

Vol. 30 No. 4, 2018

DOI:https://doi.org/10.26725/JEE.2018.4.30.6165-6172

\title{
Constraints in the Adoption of Cage Aquaculture Practices in Ernakulam District, Kerala
}

\author{
Daisy C.Kappen ${ }^{1}$, K Dinesh ${ }^{2}$ and N.D Divya ${ }^{3}$
}

\begin{abstract}
The Kerala University of Fisheries and Ocean Studies (KUFOS) implements a project entitled, "Village Adoption for Empowerment and Capacity Building Ensuring Livelihood of Fisherfolk in Central Kerala" from 2015 onwards with the objective of increasing fish production, creating employment opportunities to the fisher folk, thus ensuring livelihood security to them. The University is giving special emphasis on promoting cage aquaculture of variety of species in suitable areas and providing both technical and financial support to its beneficiary farmers for establishing small scale units. The present study was carried out in Ernakulam District of the Kerala State with the objective of identifying the constraints faced by 80 beneficiary farmers engaged in cage aquaculture of Asian seabass. The constraints faced by the cage aquaculture farmers were classified into three categories namely technical, economic and infrastructural/ administrative constraints. The most important constraints were non -availability of quality seeds, high cost of feed and lack of timely and adequate supply of seeds.
\end{abstract}

Keywords: Cage Aquaculture; Constraints; Seabass; Kerala

\section{INTRODUCTION}

Though the State of Kerala is endowed with vast resources in the form of fresh and brackish waters, the total fish production of the State from both marine and inland sector is insufficient to meet the growing demand for fish. The State depends on the neighbouring States to meet its daily requirement. Among the diversified aquaculture practices, Cage farming has enormous potential to augment fish production and it has made possible the large scale produce of commercial finfish and it is probably the most efficient way of raising fish. (Roy et al. 2015). It is ideal for poor and landless fisherfolk and is becoming popular in the State of Kerala where both fresh and brackish water resources suitable for promoting cage aquaculture are available.

Realizing the scope of cage aquaculture in the backwaters of Kerala State, Kerala University of Fisheries and Ocean Studies (KUFOS) is providing both

1. Associate Professor, College of Fisheries, Panangad, Kochi-682506, 2. Associate Professor and Head, Dept of Aqua culture, Kerala University of Fisheries and Ocean Studies, Panangad, Kochi-682506 and 3. Research fellow, Kerala University of Fisheries and Ocean Studies, Panangad, Kochi-682506

Received : 17-09-2018; Accepted : 08-10-2018 
technical and financial support to the fisherfolk and motivating them in adopting the technology of cage aquaculture of seabass under the Plan project "Village Adoption for Empowerment and Capacity Building Ensuring Livelihood of Fisherfolk in Central Kerala" funded by Government of Kerala from 2015 onwards The present study was undertaken to know the major constraints faced by beneficiary farmers of the above project in adopting the technology of cage aquaculture of Asian seabass in Kerala.

\section{METHODOLOGY}

The present study was conducted in Ernakulam District of Kerala State. This district is endowed with rich resources in the form of backwaters which is ideal for promoting cage aquaculture practices. A total of 80 beneficiary farmers of the above project doing cage aquaculture of Asian seabass was selected for the present study by using simple random sampling technique. Data were collected by using a well- structured interview schedule. The constraints faced by the cage aquaculture farmers were classified into three categories namely technical, economic and infrastructural/ administrative constraints. In all, six technical, 11 economic and 12 infrastructural/ administrative constraints in adopting the technology were identified and these constraints were measured using the procedure developed by Singh et al.(2002). The constraints were weighed on a three - point continuum scale viz. very serious, serious and not so serious respectively with weightage as 3,2 , and 1 respectively, depending upon the nature of the constraints from the view point of respondents. The constraint -wise total scores were worked out. The total scores thus obtained on each of the column were multiplied by the allotted weights. The weighted cumulative frequency method was used for computing the rank order of the constraints in each section.

\section{FINDINGS AND DISCUSSION}

The major constraints experienced by respondents in adopting the cage aquaculture practices were ranked for their relative importance on the basis of weighted cumulative frequency score. The data regarding various constraints are presented in Table 1.

Table 1 reveals that among the technical constraints, non availability of the quality seed ranked first with a cumulative score of 229 which is in conformity with the findings of Singh et al.(2002) and Haque and Ray (1983). At present, Rajiv Gandhi Center for Aquaculture (RGCA), Sirkali, Tamilnadu is the only institution commercially producing seeds of seabass and selling the seeds measuring upto $3 \mathrm{~cm}$. to the farmers. Cost of transportation involved in the purchase of seeds from there for stocking in the cages fixed along the coastal areas of Kerala will increase the total input cost of the farmers besides the cost of mortality. As the technology of seed production of seabass is complex in nature, requiring expensive infrastructural facilities including the service of technically qualified personnel, Government Departments working in 
Constraints in the Adoption of Cage Aquaculture Practices in Ernakulam District, Kerala

Table 1.

Technical Constraints in Adopting Recommended Practices in Cage Aquaculture

\begin{tabular}{|c|c|c|c|c|c|c|}
\hline $\begin{array}{l}\text { Sl. } \\
\text { No. }\end{array}$ & Constraints & $\begin{array}{l}\text { Category } \\
\text { score }\end{array}$ & Frequency & $\begin{array}{l}\text { Weighted } \\
\text { frequency }\end{array}$ & $\begin{array}{l}\text { Cumulative } \\
\text { frequency }\end{array}$ & Rank \\
\hline 1. & Lack of knowledge & $\begin{array}{l}\text { vs (3) } \\
\text { s (2) } \\
\text { nss (1) }\end{array}$ & $\begin{array}{c}2 \\
10 \\
68\end{array}$ & $\begin{array}{c}6 \\
20 \\
68\end{array}$ & $\begin{array}{c}6 \\
26 \\
94\end{array}$ & IV \\
\hline 2. & $\begin{array}{l}\text { Non availability of } \\
\text { quality seeds }\end{array}$ & $\begin{array}{l}\text { vs (3) } \\
\mathrm{s}(2) \\
\operatorname{nss}(1)\end{array}$ & $\begin{array}{c}71 \\
8 \\
-\end{array}$ & $\begin{array}{c}213 \\
16 \\
-\end{array}$ & $\begin{array}{l}213 \\
229 \\
229\end{array}$ & 1 \\
\hline 3. & $\begin{array}{l}\text { Non availability of } \\
\text { feed }\end{array}$ & $\begin{array}{l}\text { vs (3) } \\
\text { s (2) } \\
\text { nss (1) }\end{array}$ & $\begin{array}{l}58 \\
10 \\
12\end{array}$ & $\begin{array}{c}174 \\
20 \\
12\end{array}$ & $\begin{array}{l}174 \\
194 \\
206\end{array}$ & II \\
\hline 4. & $\begin{array}{l}\text { Lack of availability } \\
\text { of good quality } \\
\text { water throughout } \\
\text { the culture period }\end{array}$ & $\begin{array}{l}\text { vs ( 3) } \\
\text { s ( 2) } \\
\text { nss (1) }\end{array}$ & $\begin{array}{c}4 \\
15 \\
61\end{array}$ & $\begin{array}{l}12 \\
30 \\
61\end{array}$ & $\begin{array}{c}12 \\
42 \\
103\end{array}$ & III \\
\hline 5. & Infection of disease & $\begin{array}{l}\text { vs ( } 3 \text { ) } \\
\text { s (2) } \\
\text { nss (1) }\end{array}$ & $\begin{array}{c}- \\
5 \\
75\end{array}$ & $\begin{array}{l}- \\
10 \\
75\end{array}$ & $\begin{array}{c}- \\
10 \\
85\end{array}$ & V \\
\hline 6. & Labour scarcity & $\begin{array}{c}\text { vs ( } 3) \\
\text { s (2) } \\
\text { nss (1) }\end{array}$ & $\begin{array}{c}- \\
4 \\
76\end{array}$ & $\begin{array}{c}- \\
8 \\
76\end{array}$ & $\begin{array}{c}- \\
8 \\
84\end{array}$ & VI \\
\hline
\end{tabular}

vs - very serious

$s$ - serious

nss - not so serious

this sector can take necessary steps for starting rearing units without much capital investment in areas where there is great scope for promoting cage aquaculture of Asian seabass. As the survival rate of the fishes is positively related to the size of the fishes stocked, it is recommended to purchase the seeds measuring up to a size of $3 \mathrm{~cm}$ available at RGCA, rearing to a size of $7-8 \mathrm{~cm}$ in the rearing units established in prospective areas of the State and supplying the same to the farmers for stocking and culturing to a period of 8-10 months. It is pertinent in the case of fishes like seabass which shows cannibalism especially during the early stages of their life cycle. These rearing units can be entrusted to the farmer groups trained in rearing of seabass seeds. Such an approach will reduce the total input cost of the farmers 
Table 2.

Economic Constraints in Adopting Recommended practices in Cage Aquaculture

\begin{tabular}{|c|c|c|c|c|c|c|}
\hline $\begin{array}{l}\text { Sl. } \\
\text { No. }\end{array}$ & Constraints & $\begin{array}{l}\text { Category } \\
\text { score }\end{array}$ & $\begin{array}{l}\text { Fre- } \\
\text { quency }\end{array}$ & $\begin{array}{l}\text { Weighed } \\
\text { frequency }\end{array}$ & $\begin{array}{l}\text { Cumulative } \\
\text { frequency }\end{array}$ & Rank \\
\hline 1. & $\begin{array}{l}\text { Poor market value of the } \\
\text { product }\end{array}$ & $\begin{array}{c}\text { vs (3) } \\
\text { s (2) } \\
\text { nss (1) }\end{array}$ & $\begin{array}{c}2 \\
5 \\
73\end{array}$ & $\begin{array}{c}6 \\
10 \\
73\end{array}$ & $\begin{array}{c}6 \\
16 \\
89\end{array}$ & $x$ \\
\hline 2. & High cost of feed & $\begin{array}{c}\mathrm{vs}(3) \\
\mathrm{s}(2) \\
\mathrm{nss}(1)\end{array}$ & $\begin{array}{c}68 \\
10 \\
2\end{array}$ & $\begin{array}{c}204 \\
20 \\
2\end{array}$ & $\begin{array}{l}204 \\
224 \\
226\end{array}$ & 1 \\
\hline 3. & $\begin{array}{l}\text { Lack of money for Cage } \\
\text { construction }\end{array}$ & $\begin{array}{c}\operatorname{vs}(3) \\
\text { s( } 2) \\
\text { nss (1) }\end{array}$ & $\begin{array}{l}12 \\
13 \\
55\end{array}$ & $\begin{array}{l}36 \\
26 \\
55\end{array}$ & $\begin{array}{c}36 \\
62 \\
117\end{array}$ & VII \\
\hline 4. & Lack of credit & $\begin{array}{c}\text { vs ( } 3 \text { ) } \\
\text { s ( 2) } \\
\text { nss (1) }\end{array}$ & $\begin{array}{c}6 \\
11 \\
63 \\
\end{array}$ & $\begin{array}{l}18 \\
22 \\
63 \\
\end{array}$ & $\begin{array}{c}18 \\
40 \\
103 \\
\end{array}$ & VIII \\
\hline 5. & Lack of insurance & $\begin{array}{c}\operatorname{vs}(3) \\
\mathrm{s}(2) \\
\operatorname{nss}(1)\end{array}$ & $\begin{array}{l}40 \\
12 \\
18 \\
\end{array}$ & $\begin{array}{c}120 \\
24 \\
18 \\
\end{array}$ & $\begin{array}{l}120 \\
144 \\
162 \\
\end{array}$ & IV \\
\hline 6. & $\begin{array}{l}\text { Exploitation of farmers } \\
\text { by commission agents }\end{array}$ & $\begin{array}{c}\text { vs (3) } \\
\text { s(2) } \\
\text { nss (1) }\end{array}$ & $\begin{array}{l}40 \\
15 \\
20 \\
\end{array}$ & $\begin{array}{c}120 \\
30 \\
20\end{array}$ & $\begin{array}{l}120 \\
150 \\
170 \\
\end{array}$ & II \\
\hline 7. & $\begin{array}{l}\text { Perishable commodity } \\
\text { resulting in losses }\end{array}$ & $\begin{array}{c}\operatorname{vs}(3) \\
\mathrm{s}(2) \\
\operatorname{nss}(1)\end{array}$ & $\begin{array}{l}30 \\
23 \\
27 \\
\end{array}$ & $\begin{array}{l}90 \\
46 \\
27 \\
\end{array}$ & $\begin{array}{c}90 \\
136 \\
163 \\
\end{array}$ & III \\
\hline 8. & $\begin{array}{l}\text { Erratic local demand for } \\
\text { fish }\end{array}$ & $\begin{array}{c}\text { vs (3) } \\
\text { s (2) } \\
\text { nss (1) }\end{array}$ & $\begin{array}{c}4 \\
8 \\
68 \\
\end{array}$ & $\begin{array}{l}12 \\
16 \\
68 \\
\end{array}$ & $\begin{array}{l}12 \\
28 \\
96 \\
\end{array}$ & IX \\
\hline 9. & $\begin{array}{l}\text { Lack of transportation } \\
\text { facilities }\end{array}$ & $\begin{array}{c}\text { vs (3) } \\
\text { s( } 2) \\
\text { nss ( 1) }\end{array}$ & $\begin{array}{c}3 \\
43 \\
34 \\
\end{array}$ & $\begin{array}{c}9 \\
86 \\
34 \\
\end{array}$ & $\begin{array}{c}9 \\
95 \\
129 \\
\end{array}$ & V \\
\hline 10. & High labour charge & $\begin{array}{c}\operatorname{vs}(3) \\
\mathrm{s}(2) \\
\operatorname{nss}(1)\end{array}$ & $\begin{array}{c}9 \\
13 \\
68 \\
\end{array}$ & $\begin{array}{l}27 \\
26 \\
68 \\
\end{array}$ & $\begin{array}{c}27 \\
53 \\
121 \\
\end{array}$ & $\mathrm{VI}$ \\
\hline 11. & Poaching & $\begin{array}{c}\mathrm{vs}(3) \\
\mathrm{s}(2) \\
\mathrm{nss}(1)\end{array}$ & $\begin{array}{c}2 \\
3 \\
75 \\
\end{array}$ & $\begin{array}{c}6 \\
6 \\
75\end{array}$ & $\begin{array}{c}6 \\
12 \\
87 \\
\end{array}$ & XI \\
\hline
\end{tabular}

Vs-very serious s serious nss not so serious 
Constraints in the Adoption of Cage Aquaculture Practices in Ernakulam District, Kerala

Table 3.

Infrastructure/Administrative Constraints in Adopting Recommended Practices in Cage Aquaculture

\begin{tabular}{|c|c|c|c|c|c|c|}
\hline $\begin{array}{l}\text { Sl. } \\
\text { No. }\end{array}$ & Constraints & $\begin{array}{l}\text { Category } \\
\text { score }\end{array}$ & Frequency & $\begin{array}{l}\text { Weighed } \\
\text { frequency }\end{array}$ & $\begin{array}{l}\text { Cumulative } \\
\text { frequency }\end{array}$ & Rank \\
\hline \multirow[t]{3}{*}{1.} & \multirow{3}{*}{$\begin{array}{l}\text { Lack of timely and adequate } \\
\text { supply of seeds }\end{array}$} & vs ( 3 ) & 48 & 120 & 144 & \\
\hline & & $\mathrm{s}(2)$ & 18 & 56 & 200 & \\
\hline & & nss (1) & 14 & 12 & 212 & I \\
\hline \multirow[t]{3}{*}{2.} & \multirow[t]{3}{*}{ Lack of trained officials } & vs (3) & 4 & 12 & 12 & \\
\hline & & $s(2)$ & 14 & 28 & 40 & \\
\hline & & nss ( 1$)$ & 62 & 62 & 102 & IX \\
\hline \multirow[t]{3}{*}{3.} & \multirow{3}{*}{$\begin{array}{l}\text { Lack of frequent technical } \\
\text { supervision and guidance }\end{array}$} & vs (3) & 3 & 9 & 9 & \\
\hline & & $s(2)$ & 21 & 42 & 51 & \\
\hline & & nss (1) & 56 & 56 & 107 & VII \\
\hline \multirow[t]{3}{*}{4.} & \multirow{3}{*}{$\begin{array}{l}\text { Untimely supply of inputs and } \\
\text { other materials }\end{array}$} & vs (3) & - & - & - & \\
\hline & & $s(2)$ & 12 & 24 & 24 & \\
\hline & & nss (1) & 68 & 68 & 92 & $X I$ \\
\hline \multirow[t]{3}{*}{5.} & \multirow{3}{*}{$\begin{array}{l}\text { Lackof communication regarding } \\
\text { the services and other facilities } \\
\text { available for fish farming }\end{array}$} & vs (3) & - & - & - & \\
\hline & & $\mathrm{s}(2)$ & 9 & 18 & 18 & \\
\hline & & nss (1) & 71 & 71 & 89 & XII \\
\hline \multirow[t]{3}{*}{6.} & \multirow{3}{*}{$\begin{array}{l}\text { Location of fish collection } \\
\text { centers at distant places }\end{array}$} & vs (3) & 15 & 45 & 45 & \\
\hline & & $s(2)$ & 24 & 48 & 93 & \\
\hline & & nss (1) & 41 & 41 & 134 & III \\
\hline \multirow[t]{3}{*}{7.} & \multirow{3}{*}{$\begin{array}{l}\text { Lack of demonstration and } \\
\text { training on recommended } \\
\text { practices }\end{array}$} & vs (3) & 8 & 24 & 24 & \\
\hline & & $s(2)$ & 19 & 38 & 62 & \\
\hline & & nss (1) & 53 & 53 & 115 & $\mathrm{VI}$ \\
\hline \multirow[t]{3}{*}{8.} & \multirow{3}{*}{$\begin{array}{l}\text { Lack of literature in simple } \\
\text { language }\end{array}$} & vs (3) & 3 & 9 & 9 & \\
\hline & & $\mathrm{s}(2)$ & 20 & 40 & 49 & \\
\hline & & nss (1) & 57 & 57 & 106 & VIII \\
\hline \multirow[t]{3}{*}{9.} & \multirow[t]{3}{*}{ Lack of cold storage facilities } & vs (3) & 40 & 120 & 144 & \\
\hline & & $s(2)$ & 28 & 36 & 156 & \\
\hline & & nss (1) & 12 & 14 & 170 & II \\
\hline
\end{tabular}




\begin{tabular}{|c|l|c|c|c|c|c|}
\hline $\begin{array}{c}\text { SI. } \\
\text { No. }\end{array}$ & Constraints & $\begin{array}{c}\text { Category } \\
\text { score }\end{array}$ & Frequency & $\begin{array}{c}\text { Weighed } \\
\text { frequency }\end{array}$ & $\begin{array}{c}\text { Cumulative } \\
\text { frequency }\end{array}$ & Rank \\
\hline 10. & Poor transfer of technologies & vs (3) & 2 & 6 & 6 & \\
& & $\mathrm{~s}(2)$ & 6 & 12 & 18 & \\
& & $\mathrm{nss}(1)$ & 78 & 78 & 96 & $\mathrm{X}$ \\
\hline 11. & Lack of practical oriented & $\mathrm{vs}(3)$ & 16 & 48 & 48 & \\
& training & $\mathrm{s}(2)$ & 15 & 30 & 78 & \\
& & $\mathrm{nss}(1)$ & 49 & 49 & 127 & $\mathrm{IV}$ \\
\hline 12. & Lack of facilities for testing soil & $\mathrm{vs}(3)$ & 6 & 18 & 18 & \\
& and water quality. & $\mathrm{s}(2)$ & 24 & 48 & 66 & \\
& & $\mathrm{nss}(1)$ & 50 & 50 & 116 & $\mathrm{~V}$ \\
\hline
\end{tabular}

vs very serious $\quad s$ serious

nss not so serious

to a great extent, ensure better survival rate of the seeds and act as a solution to overcome the problem of scarcity of seeds at present, in addition to creating more employment opportunities and income to them. The other important constraints were in the order of non - availability of feed, lack of availability of good quality water throughout the culture period, lack of knowledge, infection of disease and labour scarcity.

It is evident from Table 2 that high cost of feed was the major economic constraint with a cumulative score of 226 . About $60 \%$ of the total working capital expenditure of the farmer accounts for the cost of feed, which is a major constraint in aquaculture. This finding is in accordance with the finding of Patel and Triveni (1985) who reported that high price of feed is a major constraint in poultry farming. Kappen and Thomson (2009) also identified high cost of feed as one of the major constraints in adopting the improved freshwater fish farming. Generation of low - cost technologies and preparation of the feed using locally available ingredients together with suitable Government policies will help to remedy this. Other problems were exploitation of farmers by commission agents, perishable commodity resulting in losses, lack of insurance, lack of transportation facilities, high labour charge, lack of money for cage construction, lack of credit, erratic local demand for fish, poor market value of the product and poaching.

It is evident from Table 3 that lack of timely and adequate supply of seeds was the major economic constraint with a cumulative score of 212. Vipinkumar and Asokan (2008) had also reported unpredicted seed availability as a major constraint in promoting mussel farming technology. It is natural that as the scarcity of the seeds 
is the most important technical constraint, lack of timely and adequate supply of the seeds would be a major economic constraint experienced by the farmers in adopting the technology. Other constraints were lack of storage facilities, location of fish collection centers at distant places, lack of practical oriented training, lack of facilities for testing soil and water quality, lack of demonstration and training on recommended practices, lack of frequent technical supervision and guidance, lack of literature in simple language, lack of trained officials, poor transfer of technologies, untimely supply of inputs and other materials, lack of communication regarding the services and other facilities available for fish farming.

\section{CONCLUSION}

Among the various constraints facing the cage aquaculture farmers, the most important constraints were non - availability of quality seeds ( technical constraint), high cost of feed (economic constraint) and lack of timely and adequate supply of seeds (infrastructure/ administrative constraints). Overcoming these constraints and creating an environment congenial to carry out various activities will definitely lead to an increase in fish production, providing livelihood security, creating more employment to the fisherfolk, thus leading to additional utilization of the inland water bodies of the State of Kerala. It is suggested that Department of Fisheries in collaboration with different agencies like Non-Governmental Organizations (NGO), Self Help Groups (SHGs), research stations, financial agencies and other departments concerned through planned extension activities should play a vital role in overcoming the constraints faced by the cage aquaculture farmers. Organizing the beneficiary groups and promoting group farming will increase the profitability of this innovation which will reduce both recurring and non-recurring costs.

\section{REFERENCES}

Haque \& Ray,G.L (1983). Fish Farmers

Perception of the Problems in Composite Fish Culture and Measurers Suggested by them for Increasing the Yield of Fish. Indian Journal of Extension Education. 14 ( $3 \& 4)$ : $56-61$

Joseph I.,Ignatious, B.,Joseph,S., \& Venugopalan ,K.M. (2015).Asian seabass Lates calcarifer (Bloch, 1790) as the most prospective candidate species for cage culture in Brackish water systems.Proceedings of the $5^{\text {th }}$ International Symposium on Cage Aquaculture in Asia CAA5 :207-214.

Kappen,D.C \& Thomson, K.T.( 2009). Constraints in Adoption of Recommended Technologies for Improved Freshwater Fish Farming. Journal of Extension Education 21(2) :4223-4229

Patel, A.N \& Trivedi, J.C. (1985).Constraints in Adoption of Poultry Farming in Valsad District of Gujarat State. Maharashtra Journal of Extension Education, 4:145-146

Roy.S.D,Krishnan,P.,Sarma,K.,George.G., Anirudhan A.,Angel J.R..,Murugesan,S $\&$ Varghese B.(2015). Cage Culture of Groupers in Protected Bays \& creeks of 
Journal of Extension Education

Andaman, Proceedings of the $5^{\text {th }}$ International Symposium on Cage Aquaculture in Asia CAA5 :184-190

Singh,S., Makhija, V.K., Malik, J.S. \& Dahia, S. (2002). Sunflower Production TechnologyA constraint Analysis. Indian Journal of
Social Research.43(3):195-200

Vipinkumar,V.P, \& Asokan,P.K. (2008).Mussel Farming Technology Dissemination to the Self Help Groups. Indian Journal of Extension Education 44, (1\&2):112-115 